\title{
DESIGNING AT-WORK-CONVERSATION BASED MATERIALS FOR DIPLOMA III MID- WIFERY PROGRAM
}

\author{
Surip Haryani \\ STIKES Madani Yogyakarta \\ sharyani81@gmail.com
}

\begin{abstract}
The study is aimed to find out the midwifery students' need for the materials that they can use to learn English that is appropriate with their field as midwifery students, to describe the design of At-Work Conversation based materials for midwifery Students, and to find out the effectiveness of the materials to increase the students' ability in making conversation in working situation or in improving the students' communication skill.

This is a Research and Development study ( $R$ and $D)$. The researcher used theories of ESP material design Proposed by Hutchinson and Waters and John Munby in conducting the research. The procedure of the research consists of 3 steps namely exploring, designing product, and implementation and evaluation stages. In step one, the researcher conducted need analysis and investigating the existing product for the English teaching in Midwifery program of STIKES Muhammadiyah Gombong. In step 2, the researcher designed syllabus and the first draft of the materials based on the need analysis. In step 3, the researcher tried out the materials, and asked evaluation for the first draft of the materials and revised the first draft based on the evaluation results and wrote the final draft of the materials. Before the application of the materials, the researcher conducted the pre and post test to find out the effectiveness of the designed materials to improve the students' communication skill.

Based on the need analysis the researcher found that the midwifery theme based English materials were needed in line with the competence based curriculum applied in the Midwifery Program. The researcher designed the materials based on the communicative competences for midwifery students in 9 (nine) units namely I am a Midwife, Admission in a Private Midwife Clinic, Checking Vital Signs, Antenatal Care (ANC), Assisting Labor/Childbearing, Dealing with Post partum women, Newborn Care, Family Planning and reproductive health Counseling and Providing Child health care. Each unit consists of four basic elements (sub titles). The effectiveness on the product can be shown from the improvement scores on the post test. The dependent sample T-Test statistic result shows value Sig (2-Tailed) 0.000 or less than 0.05 which means that score improvements of the pre and post test are significant. The results of the optional questioners given to the experts and students indicate positive mean and mode scores which mean that they mostly agreed with the statements on the questioners and agreed with the designed materials. It can be concluded that the materials made by the researcher are suitable for the midwifery students.
\end{abstract}

Keyword : Designing English Material, Midwifery English, R and D

\section{Introduction}

In STIKES Muhammadiyah Gombong, English is delivered in all study programs that are available in the institution. The study programs are Midwifery Program, Bachelor and Diploma III of Nursing Programs. Based on the curriculum, English is delivered for the semester I students of all programs. The institution provides internal additional English subject as the local content. The institution's academic affair asks the English teaching team to prepare the students to be ready to speak as nurse or midwife. The design of the teaching is totally given to the English Teaching Team (red: they usually have team teaching for each subject. They call the teaching team as "departemen keilmuan". The coordinator of the teaching team is obliged to design syllabi and study guides for English subject to be inline with the program that the subjects will be given. The core of the teaching is preparing the students to be able to speak as nurses or midwives. The basic competences that should be achieved by the students are speaking abilities.

Based on the institution demand, the team has been trying to develop the ESP 
course designs for each program. Teaching English for Specific Purposes (ESP) at a health institute has its own challenges. The course designs have to meet the acquired competences that the students should achieve as nursing and midwifery students. The designs of the English courses are Nursing English for Bachelor and Diploma III of Nursing programs and Midwifery English for Midwifery Program. The teacher should make such need analysis for the courses. From the field of language teaching the focus of this research will be on ESP material building. Clearly, the role of needs analysis in any ESP course is indisputable. So far, the team has created English materials and course design for both Diploma III and bachelor of nursing programs. As the Midwifery program is typically new, the ESP course design has not been completely made. The designs also should meet the students' need. Therefore, the author tried to design Midwifery English material buildings for Semester I midwifery program of STIKES Muhammadiyah Gombong.

\section{Discussion}

At-Work means in the place where we work or do our job to earn money. In context of job as midwife, At Work Conversation means the communication that a midwife does when she is doing her job as a midwife in her working place to earn money such as clinic, hospital, Private Midwife Practice Clinic (BPS), Health Centers, Maternal and Child Hospital (RSIA), etc. In working situation, a midwife does communication to patients to give health care services, to her coworkers and other people in her working place. The main conversation that will be discussed in this research is the communication on giving health care services to the clients or patients of a midwife.

Health care services done by a midwife are inline with the competences of a midwife that they have studied and mastered during their study in the midwifery program. Health care services that a midwife gives to the her patients are examining pregnant women, assisting childbirth, postpartum care, newborn care, infant care, toddler care, reproductive health, contraception or precaution counseling, family planning and adolescent counseling. In doing the services, a midwife will cer- tainly do a communication. The communication while doing the health care services to the maternal and child patients is the main point of the term "At-Work Conversation" based materials designing.

This is a Research and Development study ( $R$ and $D)$. The researcher used theories of ESP material design Proposed by Hutchinson and Waters and John Munby in conducting the research. The procedure of the research consists of 3 steps namely exploring, designing product, and implementation and evaluation stages. In step one, the researcher conducted need analysis and investigating the existing product for the English teaching in Midwifery program of STIKES Muhammadiyah Gombong. In step 2, the researcher designed syllabus and the first draft of the materials based on the need analysis. In step 3 , the researcher tried out the materials, and asked evaluation for the first draft of the materials and revised the first draft based on the evaluation results and wrote the final draft of the materials. Before the application of the materials, the researcher conducted the pre and post test to find out the effectiveness of the designed materials to improve the students' communication skill.

This study is aimed at designing the Midwifery English to develop the English communication skills of Midwifery students in STIKES Muhammadiyah Gombong Central Java. It is one of the fields in English for Specific Purposes teaching. The researcher took the theories proposed by Hutchinson and Waters as discussed in chapter II in this report.

In step 1, the researcher conducted need analysis surveys by giving questionnaires to the academic affair and to the students of first grade Midwifery program of STIKES Muhammadiyah Gombong. There are three classes in the study program and the researcher took class A as the samples that consisted of 40 students. The surveys were done to identify the curriculum and the learners' needs. The researcher also investigated the existing product used for the English teaching especially for the Bahasa Inggris Lecture given for the first grade semester 1 of Midwifery program.

In step 2, the researcher designed the syllabus or the course grid and wrote the first 
draft of the Midwifery English Materials. The materials were designed in 9 units namely I am a Midwife (unit 1), Admission in a Private Midwife Clinic (unit 2), Checking Vital Signs (unit 3), Antenatal Care (ANC) (unit 4), Assisting Labor/ Childbearing (unit 5), Dealing with Post partum women (unit 6), Newborn Care (unit 7), Family Planning and reproductive health Counseling (unit 8) and Providing Child health care (unit 9). Each unit consists of four basic elements (sub titles) i.e Conversation, Vocabularies, Language/Grammar Focus and Activities of writing, speaking, listening and reading practices.

In step 3, the researcher conducted the implementation of the first draft of the materials to the first grade students of Midwifery program. The implementations were conducted from 16 September to 30 October 2013. The schedule was taken appropriate with the schedule of Bahasa Inggris Lecture which was placed during the stated dates in Blok I STIKES Muhammadiyah Gombong especially for the Midwifery Program. Before and after the impelementations, the researcher conducted pre and post test for the students to find out whether the materials were effective or not in improving the students' communicative skills. While implementing the product, the researcher conducted the product review to the experts of English teaching and experts of the midwifery competences on 25 October 2013.
The review or evaluation from the experts' results indicated some materials of the first draft are needed to be improved and revised. The researcher summarized the revisions i.e (1) there should be more clear explanations and revisions for language/grammar focus especially in unit 1,2, 4 and 5, (2) there should be more explanation of the observation chart in unit 3 and there should be an activity session using the observation chart so that the students would understand more and use the observation chart in a real communication context, there should be glossaries for the reading texts in all unit, (4) there should be more additions on role play activities, (5) there should be more revision on long sentences, punctuations, spelling, and typing for all units, (6) the picture of a baby for language focus sessions for the sentence pattern summary would be changed appropriately for each unit, (7) there should be more additions on pictures for the course books to make it more interesting, and (8) there should be addition for pronunciation for each vocabulary and glossary sessions along with the meaning in Bahasa Indonesia. The pronunciations were provided in audio CD listening for the vocabularies, glossaries and the listening practices provided in the course book. The materials evaluation questionnaires sheets were also distributed to the students. Most of the evaluation results show positive statements. The researcher then revised the product based on the evaluations of the experts and the students.

Tabel 1. Results of the answers of Need Analysis Questioners

\begin{tabular}{|c|l|l|}
\hline No & \multicolumn{1}{|c|}{ Questions } & \multicolumn{1}{|c|}{ Explanation } \\
\hline 1 & Is English important for you? & $\begin{array}{l}\text { Most of the respondents chose answer A which means that } \\
\text { they think that learning English is really important for them as } \\
\text { candidate of nurses }\end{array}$ \\
\hline 2 & $\begin{array}{l}\text { What is your purpose in } \\
\text { learning English? }\end{array}$ & $\begin{array}{l}100 \% \text { of the respondents (40 students) chose answer A which } \\
\text { means that all of the participants have the objective to be- } \\
\text { come competent midwives and have the ability in speaking in } \\
\text { English so that they can compete in the global era, widen the } \\
\text { social network, get new experiences and understanding in } \\
\text { learning English STIKES Muhammadiyah Gombong. }\end{array}$ \\
\hline 3 & $\begin{array}{l}\text { Is English course book } \\
\text { Important for you in } \\
\text { learning English? }\end{array}$ & $\begin{array}{l}\text { The participants mostly chose answer A which means that } \\
\text { they consider that the course book is really important in } \\
\text { their learning process. }\end{array}$ \\
\hline 4 & $\begin{array}{l}\text { Do you need many exercises in } \\
\text { learning English to test your } \\
\text { ability in English? }\end{array}$ & $\begin{array}{l}\text { The participants mostly chose answer A which means that they } \\
\text { need many practices to test their ability in English. }\end{array}$ \\
\hline
\end{tabular}




\begin{tabular}{|c|l|l|}
\hline 5 & $\begin{array}{l}\text { Do you need to study } \\
\text { grammar in detail? }\end{array}$ & $\begin{array}{l}\text { Most students chose answer A which means that they } \\
\text { really need to study grammar in detail. }\end{array}$ \\
\hline 6 & $\begin{array}{l}\text { Do you need an English } \\
\text { Course book in learning } \\
\text { English that includes the } \\
\text { way in pronunciation of } \\
\text { the vocabularies? }\end{array}$ & $\begin{array}{l}\text { Most students chose answer A which means that they } \\
\text { need a course book in learning English that includes the } \\
\text { way in pronunciation of the vocabularies? }\end{array}$ \\
\hline 7 & $\begin{array}{l}\text { Do you need bilingual vo- } \\
\text { cabularies list in your } \\
\text { English course book? } \\
\text { translated in to Indonesian) }\end{array}$ & $\begin{array}{l}\text { Most students chose answer A which means that they } \\
\text { really need bilingual vocabularies list in their English } \\
\text { course book }\end{array}$ \\
\hline
\end{tabular}

\section{Findings}

The findings of the research in each step of the research procedure can be described as the following:

\section{Exploring Stages (Step one)}

\section{a. Need Analysis}

Need analyses were conducted by giving the questioners to the students and an in- terview to the curriculum/academic affair of the Midwifery Study Program of STIKES Muhammadiyah Gombong. The students of Class A of Semester 1 Midwifery Study program are chosen as the sample research consisting 40 students.

The results of the need analysis are:

1) From the students

\begin{tabular}{|c|c|c|}
\hline 8 & $\begin{array}{l}\text { Do you need materials to test } \\
\text { your listening skill? }\end{array}$ & $\begin{array}{l}\text { Most students chose answer A which means that they need } \\
\text { materials to test their listening skill. }\end{array}$ \\
\hline 9 & $\begin{array}{l}\text { Do you need materials to test } \\
\text { your reading skill? }\end{array}$ & $\begin{array}{l}\text { Most students chose answer A which means that they need } \\
\text { materials to test their reading skill. }\end{array}$ \\
\hline 10 & $\begin{array}{l}\text { Do you need materials to test } \\
\text { your speaking skill? }\end{array}$ & $\begin{array}{l}\text { Most students chose answer A which means that they need } \\
\text { materials to test their speaking skill. }\end{array}$ \\
\hline 11 & $\begin{array}{l}\text { Do you need materials to test } \\
\text { your writing skill? }\end{array}$ & $\begin{array}{l}\text { Most students chose answer A which means that they need } \\
\text { materials to test their writing skill. }\end{array}$ \\
\hline 12 & $\begin{array}{l}\text { What difficulties you Feel most } \\
\text { when learning English? }\end{array}$ & $\begin{array}{l}\text { The participants mostly chose answer } C \text { which means that } \\
\text { they commonly have difficulties in learning grammar and } \\
\text { they are lack of English vocabularies. }\end{array}$ \\
\hline 13 & $\begin{array}{l}\text { Do you feel that you have less } \\
\text { knowledge about English vo- } \\
\text { cabularies related to midwifery } \\
\text { terms/themes? }\end{array}$ & $\begin{array}{l}\text { Most students chose answer D which means that they feel that } \\
\text { they are really lack of vocabularies related to midwifery terms. }\end{array}$ \\
\hline 14 & $\begin{array}{l}\text { What skill is most difficult } \\
\text { for you when you learning } \\
\text { English? }\end{array}$ & $\begin{array}{l}\text { Most students chose answer B which means that they feel diffi- } \\
\text { cult when learning speaking skills. }\end{array}$ \\
\hline 15 & $\begin{array}{l}\text { Do you find it is hard to } \\
\text { pronounce or read } \\
\text { the vocabularies in English? }\end{array}$ & $\begin{array}{l}\text { Most students chose answer } C \text { which means that they feel a } \\
\text { bit complicated to pronounce or read the vocabularies in } \\
\text { English. }\end{array}$ \\
\hline 16 & $\begin{array}{l}\text { What model/types of English } \\
\text { course book that you want? }\end{array}$ & $\begin{array}{l}\text { Most students chose answer } C \text { which means that they need a } \\
\text { course book related to midwifery themes and completed with } \\
\text { the grammar and vocabularies explanations with the exer- } \\
\text { cises. }\end{array}$ \\
\hline 17 & $\begin{array}{l}\text { Do you need many } \\
\text { exercises in translation? }\end{array}$ & $\begin{array}{l}\text { Most students chose answer A which means that they really } \\
\text { need many exercises in translation. }\end{array}$ \\
\hline 18 & $\begin{array}{l}\text { What skill do you want to } \\
\text { Master most in learning Eng- } \\
\text { lish? }\end{array}$ & $\begin{array}{l}\text { The participants mostly chose answer D which means that } \\
\text { they need to master all combination skills (reading, listen- } \\
\text { ing, writing, speaking, pronunciation and grammar). }\end{array}$ \\
\hline
\end{tabular}




\begin{tabular}{|l|l|l|}
\hline 19 & $\begin{array}{l}\text { What kind of Teaching } \\
\text { technique do you want to } \\
\text { have in learning English? }\end{array}$ & $\begin{array}{l}\text { Most students chose answer B which means that they would like to } \\
\text { have role play related to midwifery themes as the teaching tech- } \\
\text { nique. }\end{array}$ \\
\hline 20 & $\begin{array}{l}\text { How many hours a week } \\
\text { do you need in learning } \\
\text { English? }\end{array}$ & $\begin{array}{l}\text { Most students chose answer A which means that they need more } \\
\text { than } 4 \text { hours a week to learn English. }\end{array}$ \\
\hline 21 & $\begin{array}{l}\text { How many meetings } \\
\text { do you need in a week } \\
\text { in learning English? }\end{array}$ & $\begin{array}{l}\text { Most students chose answer B which means that they have ever had } \\
2 \text { meetings in a week previously. }\end{array}$ \\
\hline 22 & $\begin{array}{l}\text { What English skill do you } \\
\text { want to master most in } \\
\text { case your preparation as a } \\
\text { midwife? }\end{array}$ & $\begin{array}{l}\text { Most students chose answer D which means that they want to master } \\
\text { all combination of all skill in English. }\end{array}$ \\
\hline 23 & $\begin{array}{l}\text { Do you need an interest- } \\
\text { ing appearance of the Eng- } \\
\text { lish course book you? }\end{array}$ & $\begin{array}{l}\text { The participants mostly chose answer A which means that they need } \\
\text { interesting appearance of the English midwifery course book. }\end{array}$ \\
\hline 24 & $\begin{array}{l}\text { Does the interesting } \\
\text { appearance of the course } \\
\text { book influence you in } \\
\text { learning English? }\end{array}$ & $\begin{array}{l}\text { The participants mostly chose answer D which means that they } \\
\text { need to master all combination skills (reading, listening, writing, } \\
\text { speaking, pronunciation and grammar). }\end{array}$ \\
\hline 25 & $\begin{array}{l}\text { What is your suggestion } \\
\text { for the course book that } \\
\text { will be given to you? }\end{array}$ & $\begin{array}{l}\text { The participants mostly wrote that they need to have an English } \\
\text { midwifery course book consisting practices of all skills in English } \\
\text { (reading, listening, writing, speaking) and added with the vo- } \\
\text { cabularies about midwifery themes. }\end{array}$ \\
\hline
\end{tabular}

2) From the academic affair.

\begin{tabular}{|l|l|}
\hline \multicolumn{1}{|c|}{ Interview Questions } & \multicolumn{1}{|c|}{ Responses } \\
\hline $\begin{array}{l}\text { What skills that the midwifery } \\
\text { program wants to be given in } \\
\text { English teaching for Bahasa } \\
\text { Inggris lecture? }\end{array}$ & $\begin{array}{l}\text { Mrs. Eka explained that the students would be given skills that are } \\
\text { relevant to make them able to speak English as candidate of mid- } \\
\text { wives. }\end{array}$ \\
\hline $\begin{array}{l}\text { Are the available English } \\
\text { Materials have been appropriate } \\
\text { with the institution's needs? }\end{array}$ & $\begin{array}{l}\text { She said that the available materials were commonly still } \\
\text { provided in general English materials }\end{array}$ \\
\hline $\begin{array}{l}\text { Do you want an English } \\
\begin{array}{l}\text { Course book available for } \\
\text { the English lecture for the } \\
\text { semester I students? }\end{array}\end{array}$ & $\begin{array}{l}\text { She answered that she really wanted the English teacher to provide } \\
\text { an English course book for the students especially which is relevant } \\
\text { for the midwifery field }\end{array}$ \\
\hline $\begin{array}{l}\text { What kind of English course } \\
\text { book for the Bahasa Inggris Lec- } \\
\text { ture for the Semester I of Mid- } \\
\text { wifery Program? }\end{array}$ & $\begin{array}{l}\text { She answered that she wanted the English teacher to provide a mid- } \\
\text { wifery English course book that is relevant to the midwifery } \\
\text { competences such as Antenatal care (ANC), physical assessment } \\
\text { to client, childbearing/labor midwifery care, post partum, newborn } \\
\text { care, family planning and child health care }\end{array}$ \\
\hline
\end{tabular}

\section{Studying and Investigating the Existing Product}

The researcher found that the materials that had been used in the teaching process so far were general English Conversation materials. The English teacher used conversation materials taken from Interchange 3rd Edition from Cambridge English University Press. 
Table 2. Syllabus Designs for the Midwifery English Course

\begin{tabular}{|c|c|c|}
\hline $\begin{array}{l}\text { Designing } \\
\text { Product Stage } \\
\text { (Step 2) a. De- } \\
\text { signing Sylla- } \\
\text { bus Meeting }\end{array}$ & Competences & Topic \\
\hline \multirow[t]{2}{*}{1} & Students are able to: & Unit 1 \\
\hline & $\begin{array}{l}\text { a. Know and mention departments and unit in a hospital or clinic in } \\
\text { English } \\
\text { b. Mention medical jobs and professions (health care providers). } \\
\text { c. Mention jobs and professions appropriate with their working } \\
\text { place/ unit. } \\
\text { d. Make sentences using Used to / Used to be } \\
\text { e. Tell a past habit that is never been done anymore } \\
\text { f. Read and understand text about figures of midwives }\end{array}$ & $\begin{array}{l}\text { I am a } \\
\text { Midwife }\end{array}$ \\
\hline \multirow[t]{2}{*}{2} & Students are able to: & Unit 2 \\
\hline & $\begin{array}{l}\text { 1. Know vocabularies related to admission of a new patient } \\
\text { 2. Ask and answer when accepting a new patient in admission unit of } \\
\text { a midwife clinic } \\
\text { 3. Understand how to make Wh- and Yes/No questions. } \\
\text { 4. Ask and answer questions to fulfill a patient admission form in a } \\
\text { midwife clinic } \\
\text { 5. Read and understand a text about international definition of a mid- } \\
\text { wife }\end{array}$ & $\begin{array}{l}\text { Admission in } \\
\text { a Private } \\
\text { Midwife } \\
\text { Clinic } \\
\end{array}$ \\
\hline \multirow[t]{2}{*}{3} & \multirow{2}{*}{$\begin{array}{l}\text { Students are able to do a role play to fill an admission form when } \\
\text { accepting a new patient in a midwife clinic }\end{array}$} & Unit 2 \\
\hline & & $\begin{array}{l}\text { Admission in } \\
\text { a Private } \\
\text { Midwife } \\
\text { Clinic }\end{array}$ \\
\hline \multirow[t]{2}{*}{4} & Students are able to : & Unit 3 \\
\hline & $\begin{array}{l}\text { 1. Know vocabularies related to patient's vital signs } \\
\text { 2. Understand a dialogue when taking patient's vital signs } \\
\text { 3. Fill admission form } \\
\text { 4. Give instructions to the clients } \\
\text { 5. Read and understand a text about physical examination }\end{array}$ & $\begin{array}{l}\text { Checking } \\
\text { Vital Signs }\end{array}$ \\
\hline \multirow[t]{2}{*}{5} & Students are able to: & Unit 4 \\
\hline & $\begin{array}{l}\text { 1. Make suggestion in antenatal care (ANC) and for health problems } \\
\text { 2. Understand a text about pregnancy week by week }\end{array}$ & \multirow[t]{2}{*}{$\begin{array}{l}\text { Antenatal } \\
\text { Care (ANC) }\end{array}$} \\
\hline 6 & $\begin{array}{l}\text { Students are able to do role play giving suggestion for a pregnant } \\
\text { woman/client in an ANC visit }\end{array}$ & \\
\hline \multirow[t]{2}{*}{7} & Students are able to : & Unit 5 \\
\hline & $\begin{array}{l}\text { 1. Know vocabularies related to childbearing/labor process and signs } \\
\text { of labor } \\
\text { 2. Explain things that are happening when giving newborn care } \\
\text { 3. Use present continues forms } \\
\text { 4. Understand a text about signs of labor }\end{array}$ & $\begin{array}{l}\text { Assisting } \\
\text { Labor/ } \\
\text { Childbearing }\end{array}$ \\
\hline \multirow[t]{2}{*}{8} & Students are able to: & Unit 6 \\
\hline & $\begin{array}{l}\text { 1. Know vocabularies related to postpartum women } \\
\text { 2. Read and understand a text about exclusive breastfeeding }\end{array}$ & $\begin{array}{l}\text { Dealing with } \\
\text { Post partum } \\
\text { women }\end{array}$ \\
\hline 9 & $\begin{array}{l}\text { Students are able to do role play when assisting a client in childbear- } \\
\text { ing process and deal with her in post partum }\end{array}$ & \begin{tabular}{|l} 
Unit 5 and \\
Unit 6
\end{tabular} \\
\hline
\end{tabular}




\begin{tabular}{|c|c|c|}
\hline \multirow[t]{2}{*}{10} & Students are able to : & Unit 7 \\
\hline & $\begin{array}{l}\text { Know vocabularies related to newborn care } \\
\text { Explain procedure } \\
\text { Read and understand a text about how to give a baby bath }\end{array}$ & $\begin{array}{l}\text { Newborn } \\
\text { Care }\end{array}$ \\
\hline 11 & $\begin{array}{l}\text { Students are able to: } \\
\text { Know vocabularies related to family planning and reproductive } \\
\text { health } \\
\text { Ask and answer about family planning program using question } \\
\text { tags } \\
\text { Read and understand a text about client education }\end{array}$ & $\begin{array}{l}\text { Family Plan- } \\
\text { ning and re- } \\
\text { productive } \\
\text { health } \\
\text { Counseling }\end{array}$ \\
\hline \multirow[t]{2}{*}{12} & Students are able to: & Unit 9 \\
\hline & $\begin{array}{l}\text { Know vocabularies related to providing child health care } \\
\text { Explain things with present and future perfect passive tenses } \\
\text { Read and understand a text and figures about baby vaccine }\end{array}$ & $\begin{array}{l}\text { Providing } \\
\text { Child health } \\
\text { care }\end{array}$ \\
\hline 13 & $\begin{array}{l}\text { Students are able to do role play in groups in handling a client } \\
\text { from the beginning when she admits as a new client until she has } \\
\text { a newborn baby } \\
\text { (all unit review) }\end{array}$ & $\begin{array}{l}\text { Review } \\
\text { Unit 2- Unit } 9\end{array}$ \\
\hline 14 & $\begin{array}{l}\text { Students are able to do role play in groups in handling a client } \\
\text { from the beginning when she admits as a new client until she has } \\
\text { a newborn baby }\end{array}$ & $\begin{array}{l}\text { Review } \\
\text { Unit 2- Unit } 9\end{array}$ \\
\hline
\end{tabular}

\section{Designing Materials}

The materials were designed in 9 units/ topics. Those units consist of the following divisions or parts:

\section{1) Conversation}

In this part, there are conversation examples based on sequence situations starting from introduction to midwifery professions, accepting a new client in a midwife clinic, physical assessment (vital signs), Antenatal care, childbearing process, post partum mother, newborn care, family planning program consultation, child health care (9 units).

\section{2) Vocabularies}

In this part, the new vocabularies and some technical terms of midwifery are presented along with the meaning in Bahasa Indonesia. The pronunciation of the vocabularies are also provided in the audio CD listening.

\section{3) Language/Grammar Focus}

In this part, the most common grammar or language used in the conversation is discussed in detail. The examples and explanation about the language and grammar focus are given to make students easier to understand and later on can apply in the exercises.

4) Activities of writing, speaking, listening and reading practices.

In these parts, the exercises are given in 4 skills and the skills are appropriate with the topics, vocabularies and focus of the language in each unit. The listening activities are provided with exercise recorded in the listening audio CD.

\section{Implementation and Evaluation Stages} (Step 3)

\section{a. Trying Out the Materials}

The implementations were conducted during 17 of September to 30 of October 2013. Each meeting was given in 100 minutes. The researcher applied all units in the material designs of the course book for the 14 meetings in a semester. Before and after the implementation the researcher conducted pre and post test with the following results: 
Table 3. The results of the pre and post test

\begin{tabular}{|c|c|c|c|c|}
\hline NO & Group & Pre Test Score & Post Test Score & Score Improvement \\
\hline 1 & Group 1 & 12 out of 30 & 24 out of 30 & 12 \\
\hline 2 & Group 2 & 12 out of 30 & 21out of 30 & 9 \\
\hline 3 & Group 3 & 12 out of 30 & 24 out of 30 & 12 \\
\hline 4 & Group 4 & 12 out of 30 & 27out of 30 & 15 \\
\hline 5 & Group 5 & 12 out of 30 & 20out of 30 & 8 \\
\hline 6 & Group 6 & 12 out of 30 & 19 out of 30 & 7 \\
\hline 7 & Group 7 & 12 out of 30 & 23 out of 30 & 11 \\
\hline 8 & Group 8 & 12 out of 30 & 21 out of 30 & 9 \\
\hline
\end{tabular}

The

dependent T-Test result show the significant value Sig (2-Tailed) 0.000 which less than 0.05 means that score improvement of the pre and post test are significant. This indicates that the product or $\mathrm{t} h \mathrm{e}$

designed materials were effective to improve the ability of the students to make conversation.

\section{b. Evaluating the Materials (Feedback or Judgment)}

Table 4. The results of the evaluations from the students

\begin{tabular}{|c|l|l|}
\hline NO & Questions & Explanation of the Students' Answers \\
\hline 1 & $\begin{array}{l}\text { Do you still have difficulties in doing } \\
\text { all of the exercises in this book? }\end{array}$ & $\begin{array}{l}\text { Students mostly answered B which means that } \\
\text { the exercises are still a bit difficult for the students. }\end{array}$ \\
\hline 2 & $\begin{array}{l}\text { Do you think that the difficulty levels } \\
\text { of the exercises are appropriate with } \\
\text { your ability? }\end{array}$ & $\begin{array}{l}\text { Students mostly answered B which means that } \\
\text { the difficulty level of the exercises is suitable for } \\
\text { them }\end{array}$ \\
\hline 3 & $\begin{array}{l}\text { Do you think that the instructions of } \\
\text { the questions are clear, easy to read } \\
\text { and to understand with simple } \\
\text { languages? }\end{array}$ & $\begin{array}{l}\text { Students mostly answered B which means that } \\
\text { the instructions of the questions are clear, very easy } \\
\text { to read and to understand with simple languages }\end{array}$ \\
\hline 4 & $\begin{array}{l}\text { Do you think that the instructions of } \\
\text { the exercises are easy to read and to } \\
\text { understand with simple languages }\end{array}$ & $\begin{array}{l}\text { Students mostly answered B which means that } \\
\text { the instructions of the exercises are easy to read } \\
\text { and to understand with simple languages }\end{array}$ \\
\hline 5 & $\begin{array}{l}\text { Are the materials in this book } \\
\text { appropriate with your willingness as } \\
\text { a midwifery student? }\end{array}$ & $\begin{array}{l}\text { Students mostly answered A which means that } \\
\text { the materials in the book are very appropriate with } \\
\text { their willingness as midwifery students }\end{array}$ \\
\hline 6 & $\begin{array}{l}\text { Are the materials interesting and they } \\
\text { make you want to study them? }\end{array}$ & $\begin{array}{l}\text { Students mostly answered B which means that } \\
\text { the materials are interesting so that they wanted to } \\
\text { study the materials }\end{array}$ \\
\hline 7 & $\begin{array}{l}\text { Can you easily understand the } \\
\text { materials of this book? }\end{array}$ & $\begin{array}{l}\text { Students mostly answered B which means that } \\
\text { they could easily understand the materials of the } \\
\text { book }\end{array}$ \\
\hline 8 & $\begin{array}{l}\text { Is the design of the book interesting? } \\
\text { readable? } \\
\text { the design of the book is really interesting }\end{array}$ \\
\hline 10 & $\begin{array}{l}\text { Are the cover and layout performances } \\
\text { of this book interesting for you? }\end{array}$ & $\begin{array}{l}\text { Students mostly answered A which means that } \\
\text { the cover and layout performances of the book } \\
\text { are interesting for them }\end{array}$ \\
\hline
\end{tabular}


2) Evaluations from the experts

Table 5. The results of the experts' evaluation

\begin{tabular}{|c|c|c|}
\hline No & Answers of Expert A & Answers of Expert B \\
\hline \multirow[t]{6}{*}{1} & \multirow{2}{*}{\multicolumn{2}{|c|}{$\begin{array}{l}\text { Questions : What do you think of the weaknesses of the designed materials? } \\
\text { unit 1: There should be more clear explanation on the differ-| } \begin{array}{l}\text { unit 1: There should be more } \\
\text { ence between "used to" and "used to be" } \\
\text { clear explanation and practices } \\
\text { for the language focus because } \\
\text { she thought that the language } \\
\text { focus in unit } 1 \text { is rather difficult }\end{array}\end{array}$}} \\
\hline & & \\
\hline & $\begin{array}{l}\text { Unit 2: there should be enough explanation about sen- } \\
\text { tence pattern of "wh and yes/no questions" and more } \\
\text { additional examples of using modal Auxiliary verbs }\end{array}$ & Unit 2: - \\
\hline & $\begin{array}{l}\text { Unit 3: There should be more explanation of Observation } \\
\text { chart by giving other more clear explanations of what stu- } \\
\text { dents need to do with } \\
\text { the observation chart. }\end{array}$ & $\begin{array}{l}\text { Unit 3: There should be more } \\
\text { explanation on new } \\
\text { vocabularies in the reading text. }\end{array}$ \\
\hline & Unit 4: there should be glossary for the reading text & $\begin{array}{l}\text { Unit } 4 \text { : there should be an ex- } \\
\text { ample of communication } \\
\text { when doing physical assessment } \\
\text { in the conversations because the } \\
\text { title is ANC or Antenatal care }\end{array}$ \\
\hline & $\begin{array}{l}\text { Unit 5: there should be sentence patterns for the language } \\
\text { focus in unit } 5\end{array}$ & Unit 5: - \\
\hline \multirow[t]{6}{*}{2} & \multicolumn{2}{|l|}{$\begin{array}{l}\text { Questions : What things should be added or materials? } \\
\text { should be fixed from the designed }\end{array}$} \\
\hline & $\begin{array}{l}\text { Unit } 1 \text { : the conversation can be simplified, some punctua- } \\
\text { tions are missed, and need some revisions on spelling. }\end{array}$ & \multirow{5}{*}{$\begin{array}{l}\text { basically the same for all units, it } \\
\text { is necessary to give more pic- } \\
\text { tures so that the book is col- } \\
\text { orful and is more interesting }\end{array}$} \\
\hline & $\begin{array}{l}\text { unit 2: he thought the picture of the baby can be in lan- } \\
\text { guage focus is not suitable for the topic }\end{array}$ & \\
\hline & $\begin{array}{l}\text { unit 3: additional Explanation of the question forms in lan- } \\
\text { guage focus is necessary. }\end{array}$ & \\
\hline & $\begin{array}{l}\text { unit 4: the form of suggestion "you'd better to" should be } \\
\text { "you'd better + Bare infinitive (you'd better + V1). }\end{array}$ & \\
\hline & $\begin{array}{l}\text { Unit 5: the picture of a baby should be changed, not for } \\
\text { all units in language focus. It is not necessary. }\end{array}$ & \\
\hline \multirow[t]{2}{*}{3} & \multicolumn{2}{|c|}{ Questions: What do you think the about the exercises and activities in the course book } \\
\hline & $\begin{array}{l}\text { The sense of the practices are in line with the midwifery } \\
\text { themes and competences } \\
\text { It is necessary for Point D or "Activities" session in each } \\
\text { unit to be given more role play activities }\end{array}$ & $\begin{array}{l}\text { The exercises are quite easy for } \\
\text { the students. }\end{array}$ \\
\hline \multirow[t]{3}{*}{4} & \multicolumn{2}{|c|}{ Questions: What are your criticisms and suggestions for the course book? } \\
\hline & $\begin{array}{l}\text { There should be more simplification on sentences in the } \\
\text { conversation. } \\
\text { Do not use too long sentences. }\end{array}$ & $\begin{array}{l}\text { a) It is necessary to add more } \\
\text { pictures for the course books to } \\
\text { make it more interesting. }\end{array}$ \\
\hline & 49 & \\
\hline
\end{tabular}




\begin{tabular}{l}
\hline The conversation can be made more interactively \\
The grammar focus session should be given oral drill (for \\
the speaking session). \\
$\begin{array}{l}\text { There should be pronunciation pattern session where stu- } \\
\text { dents are shown how to pronounce. }\end{array}$ \\
$\begin{array}{l}\text { There should be more speaking practice. } \\
\text { There are some miss typing so it is necessary to edit } \\
\text { the materials before printing. }\end{array}$
\end{tabular}

\section{Revising the Materials}

The revisions of the designed materials were made based on the evaluation results of the experts and the students.

\section{d. Writing the Final Draft of the Materials}

After conducting the evaluation of the first draft of the materials, the researcher then made revisions and wrote the final draft of the midwifery English materials. The components of the course book would be the same but there are some revisions as stated on the prior discussion.

\section{1) Conversation}

There were some revisions on the punctuations, long sentences, additions of some communication when doing physical assessment in unit 4 (ANC) and some corrections on miss typing.

\section{2) Vocabularies}

In this part, the new vocabularies and some technical terms of midwifery are presented with the pronunciation examples given in the $\mathrm{CD}$ audio listening and the meaning in Bahasa Indonesia written in the course book.

\section{3) Language/Grammar Focus}

In this part, the most common grammar or language used in the conversation is discussed in more detail. The examples and explanation about the language and grammar focus are given to make students easier to understand and later on can apply in the exercises. At the end of the session of language/ grammar focus, the researcher put the sentence pattern as the summary for the pattern to make the students easy on understanding the discussion and examples of the sentences or the expressions.

4) Activities of writing, speaking, listening and reading practices.

In these parts, the exercises are given in 4 skills and are appropriate with the topics, vocabularies and focus of the language in each unit were involved in the activities and the researcher added glossaries for each reading text where the new vocabularies especially the technical terms presented with the meaning in Bahasa Indonesia. The pronunciations of the words were given in the audio CD audio listening so that the students could play and learn when they read the book by themselves.

\section{Conclusion}

This Midwifery English materials design is really appropriate for the Midwifery students. The course designs provide many activities related to the midwifery competences. The four skills practices along with the vocabularies and grammar topics can improve the communication skills of the midwifery students. This can be seen from the improvement of the pre and post speaking test results. The effectiveness on the product can be shown from the improvement scores on the post test. The dependent sample T-Test statistic result shows value Sig (2-Tailed) 0.000 or less than 0.05 which means that score improvement of the pre and post test are significant. The significance of the results means that the designed materials are effective to improve the students' communication skill.

\section{References}

Berwick, R. 1989. Needs Assessment in Language Programming: From Theory to Practice. New York : Pearson Education 
Borg, R.J.; G.J Dienes, 1992. The Physical Chemistry of Solids, San Diego: Academic Press

Brown, H. D. 2001. Teaching by Principles : An Interactive Approach to Language. New York : Pearson Education

Johnson, R. K. (Ed), 2001. The Second Language Curriculum, "English for Specific Purposes". Cambridge: Cambridge University Press

José Manuel Serrano, Maria Teresa Calvo, Rosa Maria Pons, 1997, "Listed" Role Plays for Students of Oral English. The Internet TESL Journal, III/9 September 1997. Murcia : Universidad de Murcia (España) Press

Gay, L.R. 1987. Competencies for Analyzing and Application. Columbus : Merril Publishing Company

Harmer, J. 2001. The Practice of Language Teaching. New York: Longman.

Hutchinson, Tom and Alan Waters. 1987. English for Specific Purposes. A Learning Centered Approach. Cambridge : Cambridge University Press.

Iwai, T., Kondo, K., S. J. D Limm, E. G Ray, H Shimizu, and J. D Brown, 1999. Japanese Language Needs Analysis. New York: Longman.

Kasworm, C. 1989. Accepted Speech: Outstanding Contribution by A Faculty Member Award. Paper presented at the meeting of the American College Personnel Association, Miami, Florida

Kranke, Karl. 1987. Approaches to Syllabus for Foreign Language Teaching. New York: Prentice Hall. Inc.

Munby, John, 1978. "Communicative Syllabus Design" Cambridge : Cambridge University Press

Nunan, D. 1998. Language Teaching Skill in Foreign Language. London: Prentice Hall. Inc.

Manser, Martin H, 1991, Oxford Learners Dictionary, Oxford : Oxford University Press.

Robinson, B. 1991, ESP Today : A Practitioner's Guide. Hemel Hempstead :Prentice Hall International.

Tomlinson, B. 1998. Materials Development in Language Teaching. Cambridge University Press.

West, R. 1994. Needs Analysis in Language Teaching., New York. Longman

\section{Electronic References}

http:/ /www.nflrc.hawaii.edu/Networks/ NW13/NW13.pdf, accessed on may, 21. 2013 at $09.15 \mathrm{AM}$

http:/ / www.thefreedictionary.com/at+work, accessed on may, 21. 2013 at 09.20 AM

http:/ / www.icicte.org/Proceedings2012/ Papers/11-1-D'Esposito.pdf accessed on May 21, 2013 at 10.22 AM

http://www.thecambridgetoolbox.org/ English/resource-box/business/ articles/espbooklet.pdf accessed on May 21, 2013 at 10.25 AM

http:/ /www.paaljapan.org/resources/ proceedings/PAAL9/pdf/Howard.pdf, accessed on May 22, 2013 at 09.33 AM

http://sastra.um.ac.id/wp-content/ uploads/2009/10/Designing-a-Modelof-Business-English-Materials-Using-aCommunicative-Approach.pdf accessed on May 22, 2013 at 11.23 AM

http:/ / asian-esp-journal.com/ April_2007_gj.php accessed on November 16, 2013, $05.00 \mathrm{AM}$

http://www.texashste.com/documents/ rubrics/role_play_rubric.pdf accessed on November 16, 2013 at 05.13 AM 